\title{
Iron-smelting Blast Furnace Discovered around Handan in Early Times
}

\author{
Yanxiang $\mathrm{Li}^{1 \text {, a }}$, Ronggeng Wang ${ }^{1,2, \mathrm{~b}}$ \\ ${ }^{1}$ University of Science and Technology Beijing (USTB), School of Metallurgical and Ecological \\ Engineering, Beijing, China \\ ${ }^{2}$ Hebei University of Science and Technology (HEBUST), School of Sciences, Shijaizhang, China \\ a liyanxiang@metall.ustb.edu.cn, ${ }^{b}$ wrg1964@163.com
}

Keywords: Iron-smelting blast furnace, furnace type, furnace building material, refractory material, iron smelting in ancient times.

\begin{abstract}
This paper discusses the blast furnaces found in iron smelting sites discovered around Handan in early times and analyzes the difference between the blast furnaces around Handan and those in different areas of China in different periods from the aspects of structure, shape, material, and age.
\end{abstract}

\section{Introduction}

A detailed technical analysis of the iron-smelting furnaces around Handan is significant for analyzing and judging the development of iron smelting technology in Handan because the iron-smelting furnace is an important tool for smelting iron.

In addition to the half-wall blast furnaces that remained in Wu'an Kuangshan Village, blast furnace ruins were found beside the bank of Wu'an Jinji Village, and more than a dozen blast furnace sites were discovered at Yingjing in Wu'an. The records of the Wu'an Cultural Relics Protection Institute show that the residual furnace wall, slag, white ash, charcoal, and furnace plug were discovered when the Guzhen site was excavated in 1975. The residual wall was inlaid in the cliff with a bottom diameter of more than $1 \mathrm{~m}$ and an unburied ore sintering block that weighed $20 \mathrm{~kg}$. The smelting technology at that time was advanced. The furnace can no longer be found in Guzhen County, but information shows us that Guzhen used blast furnaces to smelt iron at that time.

Although crucibles and crucible fragments were not discovered in all the sites, we can conclude that in early times, iron was smelt mainly by using a blast furnace in Handan, as evidenced by the smelting furnace in the Kuangshan village. No relic of crucible smelting was found.

The 12 blast furnace sites discovered around Handan could be divided into two types: round furnace and square furnace, which totaled 10 and 2 respectively. The two square furnaces located tens of meters away from each other in the same site in southwest Guzhen were built in the Song and Yuan Dynasties. The other 10 round blast furnaces were built in different dynasties. The structures and furnace building materials were significantly different as shown in table 1 .

\section{Changes In The Structure Of Iron Smelting Furnace}

Iron-smelting blast furnaces near Handan, were mostly built beside the cliff, except which located in Kuangshan Village, which were built on the ground. The high and solid cliffs could bear the greater pressure of iron-smelting furnaces and reduce the construction cost for feeding and ventilation. Although the upper parts of the remaining blast furnaces were severely damaged, the residual furnaces were all drum shaped, which could improve the capacity of the blast furnaces, result in a reasonable distribution of furnace gas, and extend furnace life while preventing the emission of heat and preserving the proper temperature in the middle of the iron-smelting furnace. With the passage of time, the blast furnaces were gradually improved similar to those in Kuangshan. The furnace top is shaped by closing up, followed by spinning over, which is easy for smelting. They were also the prototypes of modern iron-smelting blast furnaces. 
In the iron smelting sites of the Song and Jin Dynasties in the southeast of Guzhen, two square iron furnaces were found not far from each other, and they completely different from the round furnaces near Handan. They were similar to the square-shaped furnaces that appeared in the relics of the Liao Dynasty [1] in Shuichuangou Village, Yanqing County; Fanchang County, Anhui Province [2]; and Wadaoling Village, Harbin City [3]. The furnace building materials, namely, stone and soil, were the same as those discovered in the sites of Shuiquangou Village. The furnaces discovered in Fanchang County, Anhui Province, was made of rectangular gray brick, whereas the furnaces discovered in Wudaoling Village, Harbin City, were made of granite.

Table 1 Blast furnace relics discovered around Handan

\begin{tabular}{|c|c|c|c|c|c|c|}
\hline Number & Location & Shape & Size & building materials & Time & Status quo \\
\hline 1 & $\begin{array}{l}\text { Southeast of } \\
\text { Guzheng } \\
\text { County, Wu'an } \\
\text { City }\end{array}$ & $\begin{array}{l}\text { Residual round } \\
\text { bottom, drum } \\
\text { abdomen in the } \\
\text { middle }\end{array}$ & $\begin{array}{l}\text { Approximately } 2.3 \\
\mathrm{~m} \text { in diameter }\end{array}$ & Sintering soil & Han Dynasty & Charcoal \\
\hline 2 & $\begin{array}{l}\text { Wu'an Ma } \\
\text { Village } 1 \# \\
\text { furnace }\end{array}$ & $\begin{array}{l}\text { Drum shaped in } \\
\text { the middle, round } \\
\text { bottom, adduction } \\
\text { in the upper } \\
\text { portion }\end{array}$ & $\begin{array}{c}3 \mathrm{~m} \text { high , } 3.8 \mathrm{~m} \\
\text { diameter(max) }\end{array}$ & $\begin{array}{l}\text { Cliffside lined } \\
\text { stone }\end{array}$ & $\begin{array}{l}\text { Sui and Tang } \\
\text { Dynasties }\end{array}$ & Remnants \\
\hline 3 & $\begin{array}{l}\text { Wu'an Ma } \\
\text { Village 2\# } \\
\text { furnace }\end{array}$ & Round bottom & Unknown & $\begin{array}{l}\text { Cliffside sintering } \\
\text { soil }\end{array}$ & $\begin{array}{l}\text { Sui and Tang } \\
\text { Dynasties }\end{array}$ & Cross-section \\
\hline 4 & $\begin{array}{l}\text { Wu'an Ma } \\
\text { Village 3\# } \\
\text { furnace }\end{array}$ & Round bottom & $\begin{array}{l}\text { Approximately } 2 \mathrm{~m} \\
\text { in diameter }\end{array}$ & $\begin{array}{c}\text { Cliffside sintering } \\
\text { soil }\end{array}$ & $\begin{array}{l}\text { Sui and Tang } \\
\text { Dynasties }\end{array}$ & Visible bottom \\
\hline 5 & $\begin{array}{l}\text { Wu'an Ma } \\
\text { Village } 4 \# \\
\text { furnace }\end{array}$ & Round bottom & $\begin{array}{l}\text { Approximately } 2 \mathrm{~m} \\
\text { in diameter }\end{array}$ & $\begin{array}{c}\text { Cliffside sintering } \\
\text { soil }\end{array}$ & $\begin{array}{l}\text { Sui and Tang } \\
\text { Dynasties }\end{array}$ & Visible bottom \\
\hline 6 & $\begin{array}{l}\text { Wu'an } \\
\text { Economic } \\
\text { Village blast } \\
\text { furnace }\end{array}$ & Round bottom & $\begin{array}{l}2.7 \mathrm{~m} \text { in diameter, } \\
\text { approximately } 5 \mathrm{~m} \\
\text { high }\end{array}$ & $\begin{array}{l}\text { Cliffside lined } \\
\text { stone }\end{array}$ & $\begin{array}{c}\text { S\&N } \\
\text { Dynasties } \\
\text {-Sui and } \\
\text { Tang } \\
\text { Dynasties }\end{array}$ & Half \\
\hline 7 & $\begin{array}{l}\text { Blast furnace in } \\
\text { Cuilu Village, } \\
\text { Wu'an }\end{array}$ & Round bottom & Unknown & Cliff & $\begin{array}{l}\text { Tang } \\
\text { Dynasty }\end{array}$ & Sintering soil \\
\hline 8 & $\begin{array}{l}\text { Blast furnace in } \\
\text { Kuangshan } \\
\text { Village, Wu'an }\end{array}$ & Round bottom & $\begin{array}{l}6 \mathrm{~m} \text { high, } 3 \mathrm{~m} \\
\text { bottom diameter, } \\
\text { drum belly }\end{array}$ & $\begin{array}{l}\text { External } \\
\text { checkerwork, } \\
\text { lined with sandy } \\
\text { refractory soil }\end{array}$ & $\begin{array}{l}\text { Tang and } \\
\text { Song } \\
\text { Dynasties }\end{array}$ & One-third \\
\hline 9 & $\begin{array}{l}\text { Southwest 2\# } \\
\text { furnace in } \\
\text { Guzhen } \\
\text { County, Wu'an }\end{array}$ & Square & $\begin{array}{l}\text { Approximately } 2.5 \\
\text { m side length, } 2 \mathrm{~m} \\
\text { high }\end{array}$ & $\begin{array}{l}\text { Cliffside lined } \\
\text { stone }\end{array}$ & $\begin{array}{l}\text { Song, Yuan } \\
\text { and Jin } \\
\text { Dynasties }\end{array}$ & \\
\hline 10 & $\begin{array}{l}\text { Southwest 1\# } \\
\text { furnace in } \\
\text { Guzhen } \\
\text { County, Wu'an } \\
\text { City }\end{array}$ & $\begin{array}{l}\text { Big at the upper } \\
\text { portion, small on } \\
\text { the bottom; round } \\
\text { or ellipse }\end{array}$ & $\begin{array}{l}\text { Maximum diameter } \\
\text { of } 1.5 \mathrm{~m}, 3 \mathrm{~m} \text { high }\end{array}$ & $\begin{array}{l}\text { Cliffside lined } \\
\text { stone }\end{array}$ & $\begin{array}{l}\text { Song, Yuan } \\
\text { and Jin } \\
\text { Dynasties }\end{array}$ & Half \\
\hline 11 & $\begin{array}{l}\text { Southwest 3\# } \\
\text { furnace in } \\
\text { Guzhen } \\
\text { County, Wu'an }\end{array}$ & Square & $\begin{array}{c}\text { Approximately } 2 \mathrm{~m} \\
\text { side length, } 1.8 \mathrm{~m} \\
\text { high }\end{array}$ & $\begin{array}{l}\text { Cliffside lined } \\
\text { stone }\end{array}$ & $\begin{array}{l}\text { Song, Yuan, } \\
\text { and Jin } \\
\text { Dynasties }\end{array}$ & Buried in soil \\
\hline 12 & $\begin{array}{l}\text { Blast furnace of } \\
\text { Xilushang } \\
\text { Village, } \\
\text { Fengfeng }\end{array}$ & Round bottom & $\begin{array}{c}\text { Approximately } 3 \mathrm{~m} \\
\text { in diameter, } 5 \mathrm{~m} \\
\text { high }\end{array}$ & $\begin{array}{c}\text { Cliffside sintering } \\
\text { soil }\end{array}$ & $\begin{array}{c}\text { Yuan } \\
\text { Dynasty }\end{array}$ & Half \\
\hline
\end{tabular}

\section{Shape Contrast}

Volume 4 Iron Furnace of Buddhist Stone Pillar Sketch written by Zhu Guozhen in the Ming Dynasty and Volume 46 Ironworks of Spring Fair written by Sun Enze in the Qing Dynasty clearly 
described the iron smelting blast furnaces in Zunhua City in the Ming and Qing Dynasties as "one zhang two chi in depth, two chi five cun in the front, two chi seven cun in the rear, one chi six cun on the right and left respectively."

Ding Geling reported in his China Iron Ore Records that the blast furnace of Hunan Province in 1923 was " 19.8 feet in height, 15.4 feet in width at the bottom, 11 feet in width at the top. Each blast furnace could hold over 6,000 kilograms of ore, over 7,000 jin of fuel, and could smelt 1.34 tons iron a day."

The length of the ruler in Ming Dynasty was $0.32 \mathrm{~m}$. Thus, we can calculate the size of blast furnaces in Zhuhua City and Hunan Province in the Ming and Qing Dynasties, as shown in Table 2.

Table 2 Comparison of blast furnace size (unit: $\mathrm{m}$ )

\begin{tabular}{cccccc}
\hline Location & $\begin{array}{c}\text { Maximum inner } \\
\text { diameter }\end{array}$ & $\begin{array}{c}\text { Diameter at the } \\
\text { bottom }\end{array}$ & Height & $\begin{array}{c}\text { Thickness of } \\
\text { furnace wall }\end{array}$ & Time \\
\hline $\begin{array}{c}\text { Kuangshan Village, Wu'an } \\
\text { City, Hebei }\end{array}$ & 2.74 & 1.8 & 6.3 & $0.4-0.8$ & \\
$\begin{array}{c}\text { Zunhua City, Heibei } \\
\text { Province }\end{array}$ & 1.6 & & 3.8 & & $\begin{array}{c}\text { Ming and Qing } \\
\text { Dynasties }\end{array}$ \\
Hunan & & 4.5 & 5.8 & & $\begin{array}{c}\text { Republic of China } \\
\text { Tang and Song } \\
\text { Dynasties }\end{array}$ \\
$\begin{array}{c}\text { Fancang County, Anhui } \\
\text { Acheng District, }\end{array}$ & 1.15 & & 0.6 & & Jin Dynasty \\
$\begin{array}{c}\text { Heilongjiang Province } \\
\text { Tongye Town, Anyang } \\
\text { Country, Henan }\end{array}$ & 2.5 & & 1.63 & 1.0 & Song Dynasty \\
\hline
\end{tabular}

\section{Contrast Among Furnace Building Materials}

Table 3 Contrast among furnace building materials in different periods

\begin{tabular}{|c|c|c|c|}
\hline Number & Location & Time & Materials \\
\hline 1 & $\begin{array}{c}\text { Kuangshan Village, Wu'an City, Hebei } \\
\text { Province }\end{array}$ & $\begin{array}{l}\text { Late Tang Dynasty and } \\
\text { early Song Dynasty }\end{array}$ & $\begin{array}{c}\text { Stone outside, sand refractory } \\
\text { mud inside }\end{array}$ \\
\hline 2 & Tong'an County, Fujian Province & Song and Ming Dynasties & $\begin{array}{l}\text { Refractory materials made of } \\
\text { kaolin clay and chaff }[4]\end{array}$ \\
\hline 3 & Fancang County, Anhui Province & Tang and Song Dynasties & $\begin{array}{l}\text { Rectangular brick, sand-mixed } \\
\text { refractory mud [2] }\end{array}$ \\
\hline 4 & $\begin{array}{c}\text { Hualu Village, Anyang City, Henan } \\
\text { Province }\end{array}$ & Song Dynasty & White and red sandstone [5] \\
\hline 5 & $\begin{array}{l}\text { Wudaoling Village, Acheng Municipal } \\
\text { District, Heilongjiang Province }\end{array}$ & Jin Dynasty & Granite [3] \\
\hline 6 & $\begin{array}{c}\text { Relics located southeast of Guzhen, } \\
\text { Handan }\end{array}$ & Han Dynasty & Clay \\
\hline 7 & Furnace 1\# of Ma Village, Wu'an, Handan & Sui and Tang Dynasties & Stone inside, clay outside \\
\hline 8 & $\begin{array}{c}\text { Furnace 2\#-4\# of Ma Village, Wu'an, } \\
\text { Handan }\end{array}$ & Sui and Tang Dynasties & Clay \\
\hline 9 & $\begin{array}{c}\text { Blast furnace of Jingji Village, Wu'an, } \\
\text { Handan }\end{array}$ & Sui and Tang Dynasties & Stone inside, clay outside \\
\hline 10 & $\begin{array}{c}\text { Blast furnace of Cuilu Village, Wu'an, } \\
\text { Handan }\end{array}$ & Tang Dynasty & Clay \\
\hline 11 & $\begin{array}{l}\text { Furnace } 1 \#-3 \# \text { southwest of Guzhen, } \\
\text { Wu'an, }\end{array}$ & $\begin{array}{l}\text { Song, Yuan and Jin } \\
\text { Dynasties }\end{array}$ & Stone inside, clay outside \\
\hline 12 & Blast furnace of Xilushang & Yuan Dynasty & Clay \\
\hline
\end{tabular}

Many differences were noted among the furnace building materials in different regions and ages (table 3). The selection of furnace building materials depended on technology and raw materials. Local raw materials were generally adopted because their ease of acquisition could reduce construction costs (table 4). 
Table 4 Composition of white and red sandstone

\begin{tabular}{ccccc}
\hline & $\mathrm{SiO}_{2}(\%)$ & $\mathrm{CaO}(\%)$ & $\mathrm{MgO}(\%)$ & $\mathrm{Al}_{2} \mathrm{O}_{3}(\%)$ \\
\hline White sandstone & 82.39 & 8.92 & 5.63 & 3.06 \\
Red sandstone & 73.18 & 6.15 & 5.40 & 15.27 \\
\hline
\end{tabular}

According to the thirty-seventh figure "Cast Iron (Pan) Map" in the "Boil Sea Water for Salt Map" drawn in the first year of the Yuan Dynasty (1330 AD), bottle sand, clam, carbon scrap, wheat spike, and mud were used as furnace building materials. Bottle sand, now known as cylinder sand, is a quartz-rich ore that is mainly used as refractory material.

According to the Auspicious Symbol Picture Sutra in the Song Dynasty, "Carclazyte was discovered in Yangshan Village, Suzhou City. Every year, officials took more than 10,000 jin for casting coins of Jiantang Baoxing Coin Casting Bureau. Looking like power, carclazyte could be taken as coating material." Wu Junzhi in the Song Dynasty wrote in Pingjiang Mansion Annals that "carclazyte was discovered in Yangshan Village. It could be obtained by digging into a mountain to create a pit that measures hundreds of meters. It looked like mud and hardened when blown by wind, but it was incomparably fine. It was always used as halloysitum album." According to Prehistoric Fossils in Yangshan written by Gu Jiegang and edited by Wang Xuhua, "People are worrying that the rich ancient cultural heritage of Suzhou may disappear because carclazyte had almost been destroyed by miners (carclazyte and electroceramics can be found in Yangshan Mountain)." Judging from the above information, carclazyte belongs to the family of kaolin minerals, most of which are potassium feldspars, which can be commonly used as refractory materials.

Carbon is a good heat-resistant material in a non-oxidizing atmosphere. It can increase the fire resistance of the furnace wall and the resistance to slag erosion. Wheat spike is added to make the refractory mud tough and tensile.

According to the above information, the blast furnace building materials in the Song and Yuan Dynasties included refractory mud with bottle sand, carbon dust, and wheat spike; refractory mud with kaolinite and chaff; refractory bricks with coarse sand grains; and fire-resistant white and red sandstone. The iron-smelting furnaces in Kuangshan Village were made of local stones and refractory clay, not carbon scrap and wheat spike, among other materials.

Table 3 shows that before the Tang and Song Dynasties, clay was used as a furnace building material around Handan to fill the mold of blast furnaces that were dug following the topography of a cliff. After the Tang and Song dynasties, masonry was gradually added. The shape of the blast furnace was built directly on a flat ground with stones, lined by refractory materials. Stone furnace could has a high pressure, high temperature, high intensity, and deformation resistance. A large and durable blast furnace can be built with the help of a blower.

Iron-smelting blast furnaces around Handan, were mostly built beside the cliff, except those in Kuangshan Village built on the ground, The furnace walls were made of clay. Some furnaces were reinforced by stones. The iron-smelting furnaces in Jingji Village embodied the evolution of furnace building technology from clay to stone plus clay. The materials available for iron-smelting furnaces were mostly clay, and only Kuangshan Village used sandy refractory soil in building blast furnace.

According to Liu Haifeng [6], most iron-smelting furnaces in the Warring States Period and the Eastern Han Dynasty had only simple furnace walls and no special furnace lining. In the Tang and Song Dynasties, sandy material appeared inside the stone furnace, consistent with that discovered in this study.

Huang Xing [1] studied the shaft furnace model in Ancient China and arrived at similar conclusions: The iron-smelting furnaces from the Warring States Period to the Han Dynasty were mostly made of rammed earth. The shaft furnaces in the Tang and Song dynasties were gradually made of stone. 
The above analysis shows that the evolution of iron-smelting blast furnaces around Handan is similar to that in other places in China, thereby indicating a close technical exchange between the iron-melting technology in Handan and that in the rest of China.

\section{References}

[1]. Huang Xing. Research on Shape of Shaft Iron-Smelting Furnace in Ancient China [D]. Beijing University of Science and Technology, China 2014.P.71-76.

[2]. Hu Yueqian. Ancient Iron-Smelting Sites Discovered in Fanchang County [J]. Cultural Relics, 1959 (7): 74.

[3]. Wang Yongxiang. Preliminary Study on Ancient Metallurgical Ruins in Wudaoling Village, Acheng County [J]. Heilongjiang Daily, 1962, 11.13.

[4]. Chen Zhongguang. Ancient Iron-Smelting Sites Discovered in Tongan County [J] Cultural Relics, 1959 (2): P.75.

[5]. Authoring group of Brief history of metallurgical industry in China, Beijing Iron and Steel Institute. Brief history of metallurgical industry in China $[\mathrm{M}]$. Beijing: Science Press, 1978.P.182.

[6]. Liu Haifeng. Preliminary Study on Materials of Iron-smelting Furnace Wall in Ancient China [D]. Beijing University of Science and Technology, China 2015.P.85. 